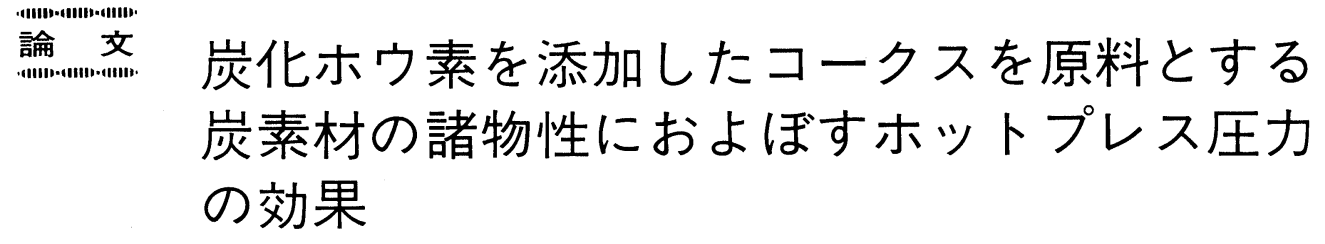

宮 崎憲 治*・萩尾剛 ${ }^{*}$ 小小林和 夫*

（昭和 57 年 3 月 26 日受理）

\title{
Effect of Hot-pressing Pressure on Some Properties of Polycrystalline Graphite made from Coke Powder with addition of Boron Carbide
}

\author{
Kenji Miyazaki, Tsuyoshi Hagio and Kazuo Kobayashi \\ Government Industrial Research Institute, Kyushu \\ Shuku-machi, Tosu-shi, Saga-ken, 841, Japan
}

Polycrystalline graphites were made from a calcined pitch coke powder with boron carbide $\left(\mathrm{B}_{4} \mathrm{C}\right)$ additive in amounts varying from 0 to $16.7 \mathrm{wt} \%$ by hot-pressing at $2200^{\circ} \mathrm{C}$ under various pressures from 20 to $400 \mathrm{~kg} / \mathrm{cm}^{2}$. The effect of hot-pressing pressure was investigated on some properties such as density, bending strength, electrical resistivity, graphitization degree and oxidation behaviour of the hot-pressed solids.

It was found that the density and bending strength of the hot-pressed solids increased remarkably with increasing hot-pressing pressure. The obtained values were, however, depended on the content of $\mathrm{B}_{4} \mathrm{C}$ additive; that is, in the cases of $4.8 \mathrm{wt} \%$ and $16.7 \mathrm{wt} \% \mathrm{~B}_{4} \mathrm{C}$ additions, the bending strength was about $900 \mathrm{~kg} / \mathrm{cm}^{2}$ and about $1400 \mathrm{~kg} / \mathrm{cm}^{2}$ respectively for solids made at a maximum pressure of $400 \mathrm{~kg} / \mathrm{cm}^{2}$.

Electrical resistivity decreased with the increase of hot-pressing pressure and was about $0.5-0.6 \times 10^{-3}$ ohm-cm for all the hot-pressed solids with $\mathrm{B}_{4} \mathrm{C}$ additive made at $400 \mathrm{~kg} / \mathrm{cm}^{2}$.

The $d_{(002)}$ spacings of the hot-pressed solids expanded slightly and three dimensional disordering of graphite structure occurred with the increase of hot-pressing pressure. Their graphitization degree, however, progressed much more than those for the solids without $\mathrm{B}_{4} \mathrm{C}$ additive. The degradation behaviour of graphite structure is thought to be due to boron diffusion and its interstitial occupation between layers in addition to substitutional positions.

All the hot-pressed solids made with $\mathrm{B}_{4} \mathrm{C}$ additive showed excellent resistance against air oxidation and $\mathrm{H}_{2} \mathrm{SO}_{4}-\mathrm{HNO}_{3}$ acid solution, compared with those of solids without $\mathrm{B}_{4} \mathrm{C}$ additive and some conventional graphites.

\section{1. 緒言}

著者ら ${ }^{1)}$ は先に少量(約 $5 \mathrm{wt} \%$ )の炭化ホウ素を仮焼ピ ッチコークス粉末に添加し，ホットプレス装置により 200 $\mathrm{kg} / \mathrm{cm}^{2}$ の圧力下で加圧焼結を試みたととろ，焼成温度 が $2000^{\circ} \mathrm{C}$ 以上に打いて焼成体のち密化および黒鉛化が著 しく進行することを見い出し，とのコークス粉末の焼結と

\footnotetext{
*工業技術院九州工業技術試験所： 7841 佐賀県鳥栖市 宿町
}

黒鉛化は, 炭化ホウ素中のホウ素が $2000^{\circ} \mathrm{C}$ 以上でコーク スの黒鉛構造中の炭素原子之置換固溶するととにより促進 されることを明らかにした。さらに, 炭化ホウ素添加量が 增加した場合の焼成体の組成, 密度, 機械的強度, 電気 比抵抗抢よびコークスのX線パラメータの变化について 報告した ${ }^{2,3)}$ 。その結果，ホウ素の置換型固溶限界量は， 炭化ホウ素添加量が $10 \mathrm{wt} \%$ 以内の範囲では 1 2 wt\%で あるとと、コークスの黒鉛化は添加量 5 10 wt\%で最む 促進され，添加量がこれより多くなると黒鉛化は逆に低 
下するととを見い出し，乙の黒鉛化度の低下はホウ素が 置換型に加えて, 侵入型としてもコークス中に固溶する ことによるあのと推定した。

以上の報告は，ホットプレス圧力がすべて $200 \mathrm{~kg} / \mathrm{cm}^{2}$ の一定圧力下の場合であり，ホットプレス圧力が変化す れば, 当然, 焼成体への諸特性およびコークスの黒鉛化 度も変わってくることが予想された。

そてで, 著者ら゙) はホットプレス圧力の影響を調べるた め, 三酸化ホウ素を $9.1 \mathrm{wt} \%$ (ホウ素量としては $2.8 \mathrm{wt} \%$ ) 添加したコークスについて，圧力が $70 \mathrm{~kg} / \mathrm{cm}^{2}$ から 400 $\mathrm{kg} / \mathrm{cm}^{2}$ の範囲で実験した結果, 圧力の増大とともに焼 成体のかさ密度および強度は著しく増加するが、コーク スのX線パラメータには压力はほとんど影響をおよぼさ ない結果を得た。

しかしながら，上記のホットプレス圧力の効果に関す る実験では，三酸化ホウ素の添加量は $9.1 \mathrm{wt} \%$ ，ホウ素 としては $2.8 \mathrm{wt} \%$ であり，焼成中に黒鉛ダイス中へ逃げ る量などを考慮すると, 置換型固溶限界量に十分達して いないてとが考えられた。また, 添加剤として三酸化木 ウ素を用いた場合, ガスの発生があるために, その添加 量は $10 \mathrm{wt} \%$ 前後が安全の面から限界と考えられる。

そこで, 今回, 炭化ホウ素を用い, 十分に置換型固溶 限界量をこえる量, すなわち, 4.8〜 $16.7 \mathrm{wt} \%$ の範囲(ホ ウ素量としては 3.8 13.1 wt\%)の場合について，ホット プレス圧力を $20 \mathrm{~kg} / \mathrm{cm}^{2}$ から $400 \mathrm{~kg} / \mathrm{cm}^{2}$ の範囲で変え, 得られる焼成体の諸特性抢よびコークスの黒鉛化性にお よぼすホットプレス圧力の効果について実験を行ったの で報告する。

\section{2. 試料および実験方法}

\section{1 試料調製}

実験に供したコークス原料は，仮焼ピッチコークス（日 鉄化学工業(株)製)で, 乙れを $149 \mu \mathrm{m}$ 以下に粉砕し，乙の $50 \mathrm{~g}$ ずつをさらにらいかい機で約 40 分間粉砕した粒子径 の大部分が $50 \mu \mathrm{m}$ 以下の微粉末である。添加する炭化ホ ウ素粉末としては, 粒径 1 2 $2 \mu \mathrm{m}$ の市販の微粉末(電気化 学(株)製)を使用した。添加はコークス粉末 100 に対し 炭化ホウ素 5,10 および 20 の重量比(炭化ホウ素添加量 は，それぞれ，4.8，9.1 执よび $16.7 \mathrm{wt} \%$, また, ホウ素 量としては 3.8，7.1 および $13.1 \mathrm{wt} \%$ となる)で混合し， それぞれの総量 $60 \mathrm{~g}$ をさらにらいかい機で 30 分間混合 粉砕したあのを実験試料とした。また, 比較のため, 無 添加のコークス粉末 $60 \mathrm{~g}$ を同様にらいか心機で粉砕し， 実験に供した。

\section{2. 実験方法}

実験装置としては， 既報 ${ }^{1)} に$ 示した高周波誘導加熱方
式のホットプレス装置(富士電波工業(株)製)を, 発熱体と しては外径 $100 \mathrm{~mm} \phi$, 内径 $30 \mathrm{~mm} \phi$, 高さ $100 \mathrm{~mm}$ の円筒 形黒鉛モールドを用いた。ホットプレス压力は 20〜400 $\mathrm{kg} / \mathrm{cm}^{2}$ の範囲の 5 点とした。昇温は各実験とも同一軌 跡をたどるよう電圧調整によりコントロールした。測温 は光高温計により，黒鉛モールド壁をプリズムを通して 行った。各試料と屯, $2200^{\circ} \mathrm{C}$ で 60 分間保持した後, 電 源を切り，室温まで泠却した。冷却した黒鉛モールド中 より焼成体を取り出し，各物性の測定を行った。

\section{3 焼成体の物性測定}

\section{1) 密 度}

焼成体のかさ密度はマイクロメータおよびノギスによ る焼成体の実測体積とその重量から求めた。焼成体の相 対密度としては，かさ密度の焼成体の理論密度に対する 百分率の值であらわした。焼成体の理論密度を求める場 合, 炭化ホウ素の密度を $2.52 \mathrm{~g} / \mathrm{cm}^{3}$ とし, コークスの密 度としては, 各焼成体試料のX線回折より求めたコーク スの格子定数から計算したX線密度をそれぞれの場合に 応じて用いた。また，コークスと炭化ホウ素の混合比は， 実験前後において変化しないものと仮定した。実際には， 炭化ホウ素中のホウ素がコークス中に固溶する現象があ り，その量は 1〜2 wt\%前後，また，焼成中にモールド 中ににげるホウ素量は 1 2 $\mathrm{wt} \%$ 前後と推定されている が $^{3)}$ ， ホウ素と炭素の原子量が近似しているととおよび モールド中等へにげる量が少ないととから相対密度の 変化を論じる場合には，著しい影響がないすのと考え た。

2）曲げ強度, 弾性率および破断面観察

曲げ強度は，焼成体より長手方向が焼成時の加圧方向 と垂直となる長方形試片を切り出し, サンドペーパー (1000 番)にて表面を研磨した約 $25(1) \times 8(\mathrm{w}) \times 5(\mathrm{t})$ $\mathrm{mm}$ の試片を作成して，支点間 $20 \mathrm{~mm}$ の 3 点支持法によ り，室温条件で加圧面之平行な試験片面に荷重を加えて

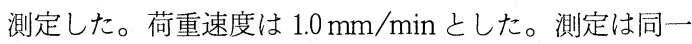
実験条件につき，それぞれ 2 試料おこなった。また，弾 性率は曲げ強度測定時得られる荷重一変位曲線より求め た。

また, 破断された試片について, 光学顕微鏡によりホ ットプレス方向に平行な面の破断形態を観察した。

3）電気比抵抗

電気比抵抗は, 定電流電位差法 (4 端子法)により, 曲 げ試験用試片の長手方向の抵抗值を測定した。端子間距 離は約 $9 \mathrm{~mm}$ とし, 電流は $0.40 \mathrm{~A}$ とた。測定試料数は 同一条件について 2 試料とした。また，各試料の電気比 抵抗值としては，同一試片の各 4 面についてそれぞれ 6 回ずつ測定し，相加平均した值を用いた。 
1982 （No. 111）炭化ホウ素を添加したコークスを原料とする炭素材の諸物性におよぼすホットプレス压力の効果

\section{4) X線回折}

焼成体中のコークスの $d_{(002)}$ 值, $d_{(110)}$ 值, 見掛けの結 晶子の大きさ $L_{c(004)}$ および $L_{c(112)}$ を学振法に準じて測定 した。測定は粉末X線回折装置により, $\mathrm{CuK}_{\alpha}$ 線, 黑鉛 モノクロメータおよびシンチレーション計数管使用の条 件でおてなった。

5）空気酸化および湿式酸化

各ホットプレス压力下で得られた焼成体より，約 $10 \times$ $5 \times 5 \mathrm{~mm}$ の試片を切り出し，それをさらにサンドペーパ -(1000 番)で研磨したものを空気酸化执よび湿式酸化 試験用試片とした。空気酸化試験はるつぼ型電気炉を用 いて，試片のはいったアルミナるつぼを，空気中，800 ${ }^{\circ} \mathrm{C} て ゙ 一$ 定時間放置することによりおこなった。また，湿 式酸化試騃は, 硫酸と硝酸の混酸(混合比 $9: 1$ ) に室温中 で一定時間試験片をどぶづけにしておてなった。試験後， 形態観察を行い, 試験前と比較することにより, それぞ れの耐酸化性を調べた。同時に, 市販の炭素材“A”(大和 田カーボン工業(株)製, OT-5200) および “B”(東洋炭 素(株)製，IG-11）についても同様な実験を行い，本焼 成体試料との比較を行った。なお, 空気酸化試験は, 試 験毎の対空気接触の度合の相違をふせぐために, 本焼成 体試料と比較用市販炭素材試片を同一アルミナるつぼに 入れて, 一度に行った。

\section{3. 結果および考察}

\section{1 かさ密度および相対密度}

ホットプレス压力の変化にともなう各焼成体のかさ密 度抢よび相対密度の変化をFig.1 および Fig. 2 に示す. 図からわかるように, 圧力が増加するにしたがって, 各 試料ともかさ密度および相対密度は増加する。とくに压力

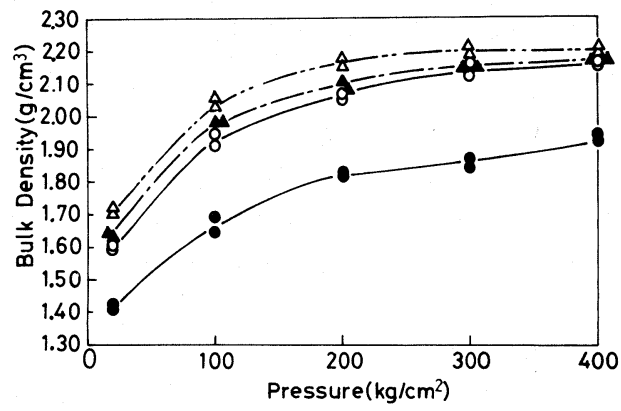

Fig. 1 Changes of bulk density of the compacts hot-pressed at $2200^{\circ} \mathrm{C}$ with hot-pressing pressure.

: no addition,

: $4.8 \mathrm{wt} \%$ boron carbide addition,

$\Delta: 9.1 \mathrm{wt} \%$ boron carbide addition, $\triangle: 16.7$ wt $\%$ boron carbide addition

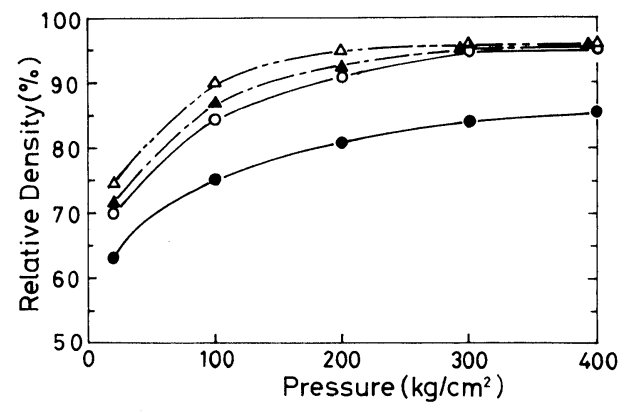

Fig. 2 Changes of relative density of the compacts hot-pressed at $2200^{\circ} \mathrm{C}$ with hot-pressing pressure.

: no addition,

: 4.8 wt $\%$ boron carbide addition,

$\Delta: 9.1$ wt $\%$ boron carbide addition,

$\triangle: 16.7 \mathrm{wt} \%$ boron carbide addition

が $200 \mathrm{~kg} / \mathrm{cm}^{2}$ までの増加が著しい。压力が $200 \mathrm{~kg} / \mathrm{cm}^{2}$ 以下では炭化ホウ素添加量による差があらわれており， 添加量が多いほど高密度化している。压力が $300 \mathrm{~kg} /$ $\mathrm{cm}^{2}$ 以上では相対密度は95〜96\%のほぼ一定の值とな った。一方, コークス単味の場合む同様に圧力の増加之 ともに焼成体の密度は増加するが，その絶対值は全体に かなり低く，圧力 $400 \mathrm{~kg} / \mathrm{cm}^{2}$ であ相対密度は約 $85 \%$ に とどまった。

\section{2 曲げ強度, 弾性率および破断面観察}

ホットプレス圧力と各焼成体の曲げ強度の関係を Fig. 3 亿示す。炭化ホウ素添加焼成体では，压力が増加する ほど曲げ強度も大きくなり，その傾向は添加量が多い試 料ほど著しい。すなわち，4.8 wt\% および $9.1 \mathrm{wt} \%$ 添加 の場合には, 圧力の増加とともにほぼ直線的に曲げ強度 あ増加し, 压力 $400 \mathrm{~kg} / \mathrm{cm}^{2}$ ではそれぞれ約 $900 \mathrm{~kg} / \mathrm{cm}^{2}$

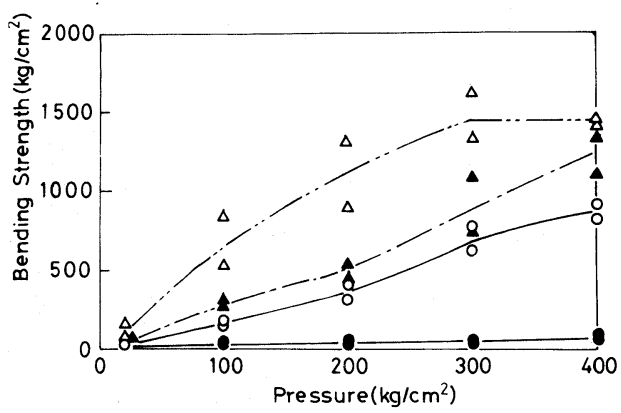

Fig. 3 Changes of bending strength of the compacts hot-pressed at $2200^{\circ} \mathrm{C}$ with hot-pressing pressure.

: no addition,

: 4.8 wt $\%$ boron carbide addition,

$\Delta: 9.1$ wt $\%$ boron carbide addition, $\triangle: 16.7 \mathrm{wt} \%$ boron carbide addition 
䄱よび約 $1200 \mathrm{~kg} / \mathrm{cm}^{2}$ の值を示す。また， 16.7

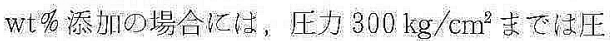

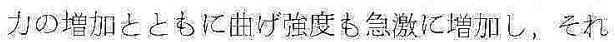

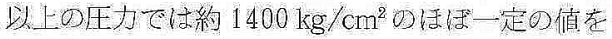
示した。一う，無添扣陚料では圧力者增加しても 强度のある焼成体は得られなか力った。

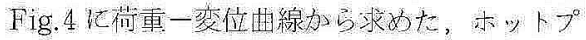

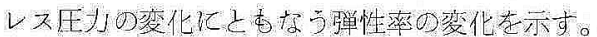

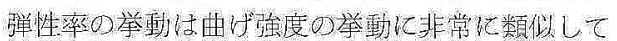

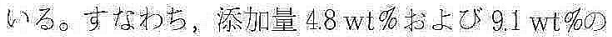

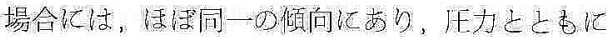

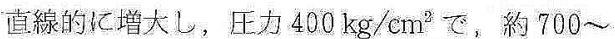
$800 \mathrm{~kg} / \mathrm{mm}^{2}$ \%值在示した。 $16.7 \mathrm{wt}$ \% 添加尚婸合 は，压力 $200 \mathrm{~kg} / \mathrm{cm}^{2}$ むでは急激比上晎し，300 $\mathrm{kg} / \mathrm{cm}^{2}$ 以上ては絢 $1200 \mathrm{~kg} / \mathrm{mm}^{2}$ ○はばー定の值 犊した。

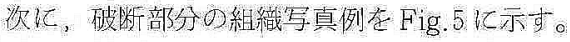

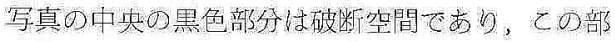

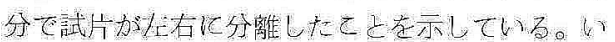

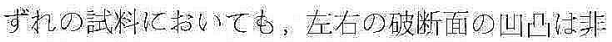

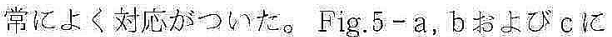

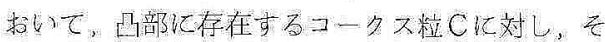
の対面である先印で示した凹部付コークス䊁し

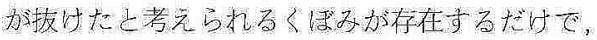
コータス精C上同一粒であったを考えられるコ一

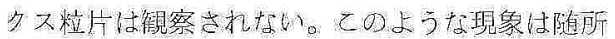

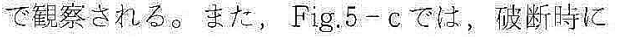

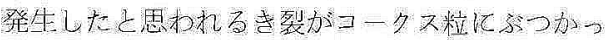

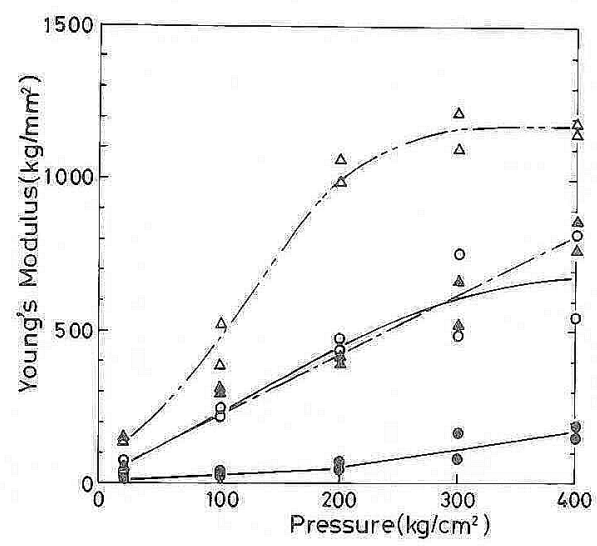

Fig. 4 Changes of Young's modulus of the compacts hot-pressed at $2200^{\circ} \mathrm{C}$ with hot-pressing pressure.

- no addition,

$0: 4.8$ wt $\%$ boron carbide addition,

: 9.1 wt \% boron carbide addition,

$\triangle: 16.7$ wt $\%$ boron carbide addition
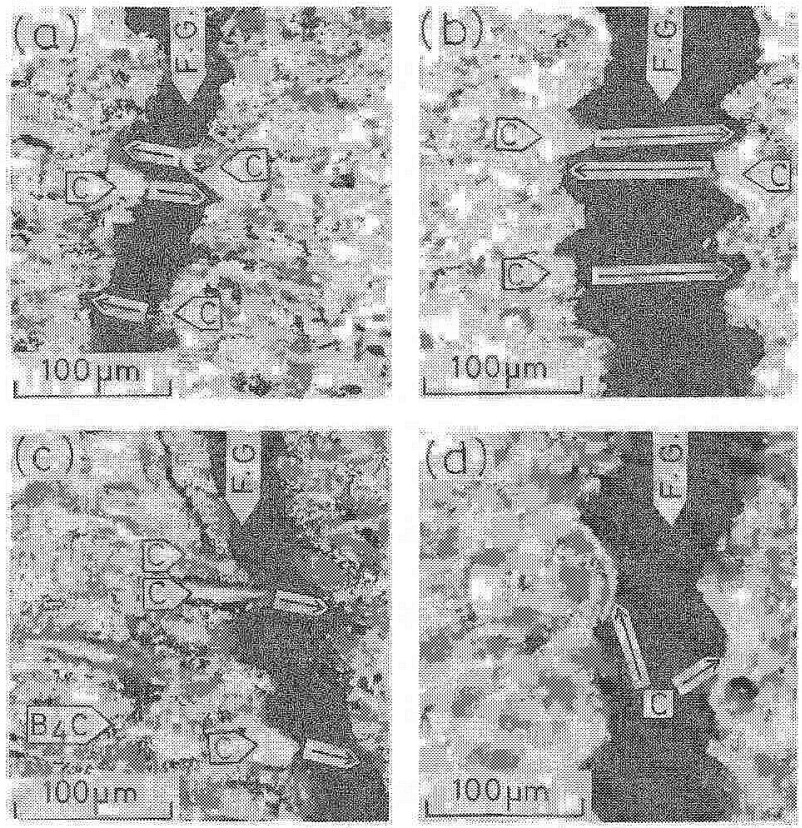

Fig. 5 Microphotographs of the fractured part of the compacts hot-pressed at $2200^{\circ} \mathrm{C}$ with hot-pressing pressure.

(a.) $4.8 \mathrm{wt} \%$ boron carbide addition, 300 $\mathrm{kg} / \mathrm{cm}^{2}$,

(b) $9.1 \mathrm{wt} \%$ boron carbide addition, 300 $\mathrm{kg} / \mathrm{cm}^{2}$,

(c) 16.7 wt \% boron carbide addition, 400 $\mathrm{kg} / \mathrm{cm}^{2}$

(d) $9.1 \mathrm{wt} \%$ boron carbide addition, 100 $\mathrm{kg} / \mathrm{cm}^{2}$.

F.G.: gap formed by fracture.

C: coke, $\mathrm{B}_{4} \mathrm{C}$ : boron carbide.

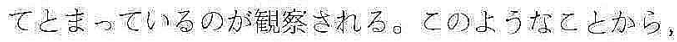

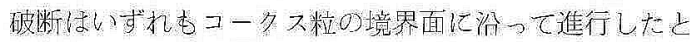

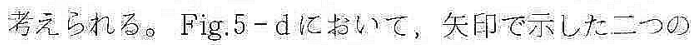

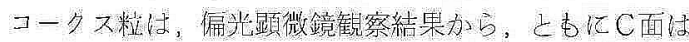

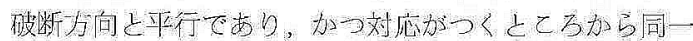

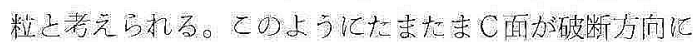

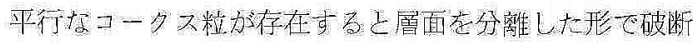
したところす観察さ机た。

\section{3 電気比抵抗}

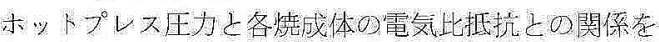

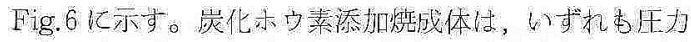

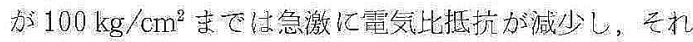

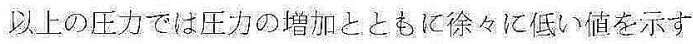
ようになる。添加量の多少による電知比抵抗值心差は余

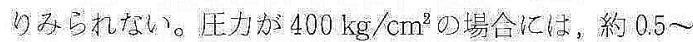

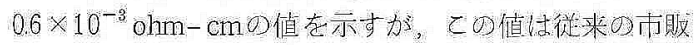




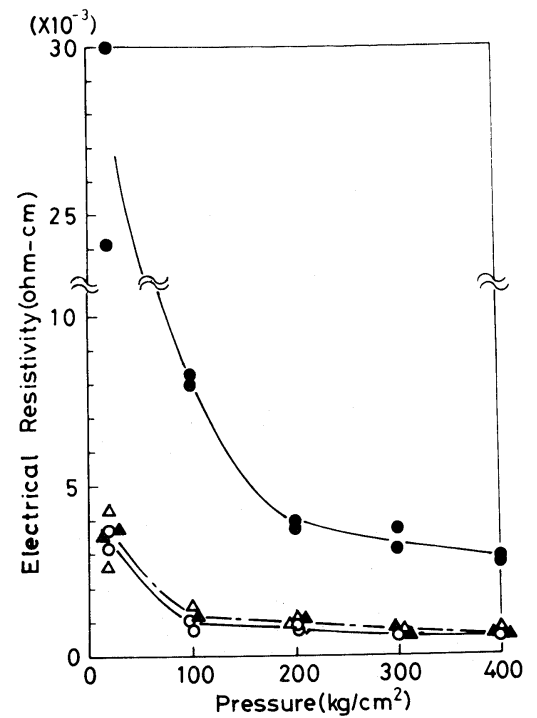

Fig. 6 Changes of electrical resistivity of the compacts hot-pressed at $2200^{\circ} \mathrm{C}$ with hot-pressing pressure.

- : no addition,

: $4.8 \mathrm{wt} \%$ boron carbide addition,

$\Delta$ : $9.1 \mathrm{wt} \%$ boron carbide addition,

$\triangle: 16.7 \mathrm{wt} \%$ boron carbide addition

の人造黑鉛材の電気比抵抗と比較して最小の部類に属す る。一方，無添加試料に扔いても圧力の増大とともに電 気比抵抗值は減少するが, 全体にその值は高く, $400 \mathrm{~kg}$ $/ \mathrm{cm}^{2}$ の場合であ, $2 \sim 3 \times 10^{-3} \mathrm{ohm}-\mathrm{cm}$ の值であった。

\section{$3.4 X$ 線回折}

ホットプレス压力とコークスの $d_{(002)}$ 抢よび $L_{c(004)}$ の 関係を Fig.7 および Fig.8 亿示す。 $d_{(002)}$ 值は，压力が $20 \mathrm{~kg} / \mathrm{cm}^{2}$ と低い場合, 添加量によらずほぼ約 $3.358 \AA$

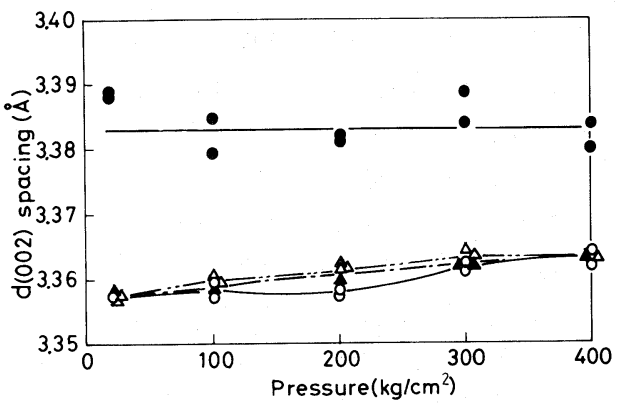

Fig. 7 Changes of $d_{(002)}$ spacing of coke with hot-pressing pressure.

: no addition,

: $4.8 \mathrm{wt} \%$ boron carbide addition,

$\Delta: 9.1 \mathrm{wt} \%$ boron carbide addition, $\triangle: 16.7 \mathrm{wt} \%$ boron carbide addition

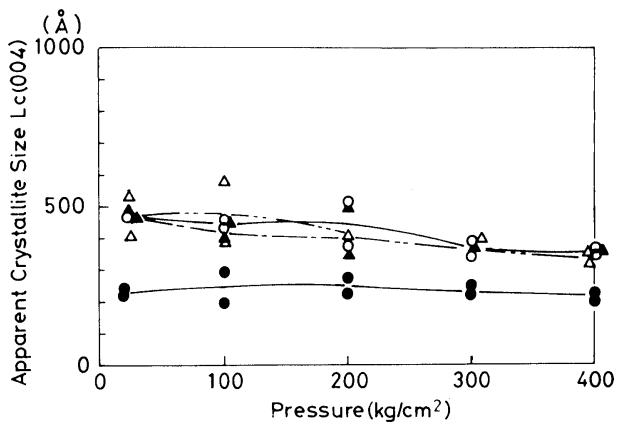

Fig. 8 Changes of apparent crystallite size, $L_{c(004)}$, of coke with hot-pressing pressure.

: : no addition,

: $4.8 \mathrm{wt} \%$ boron carbide addition,

$\Delta$ : $9.1 \mathrm{wt} \%$ boron carbide addition,

$\triangle: 16.7 \mathrm{wt} \%$ boron carbide addition

であるが，圧力の増加ととあにその值は少しずつ増大し， $400 \mathrm{~kg} / \mathrm{cm}^{2}$ では約 3.362 丹を示した。一方, 無添加の場

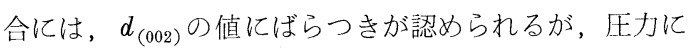
依存せず，3.38〜3.39 ^の間でほぼ一定とみてもよいと 思われる。見掛けの結晶子の大きさ， $L_{c(004)}$ は, 無添加 の場合には圧力に関係なくほぼ $200 \AA$ 之一定であるが， 炭化ホウ素添加の場合には, $20 \mathrm{~kg} / \mathrm{cm}^{2}$ の約 400 500

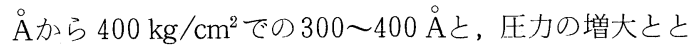
あに見掛けの結晶子の大きさが次第に減少している傾向 が認められる。

ホットプレス压力とコークスの $d_{(110)}$ の関係を Fig. 9 飞示す。 $d_{(110)}$ 值は，無添加抢よび炭化ホウ素添加試料 と屯に，圧力に依存せず，それぞれ約 1.230 および 1.232 ^のほぼ一定の值を示す。

三次元黑鉛構造の規則性の度合を示す (112)回折線の

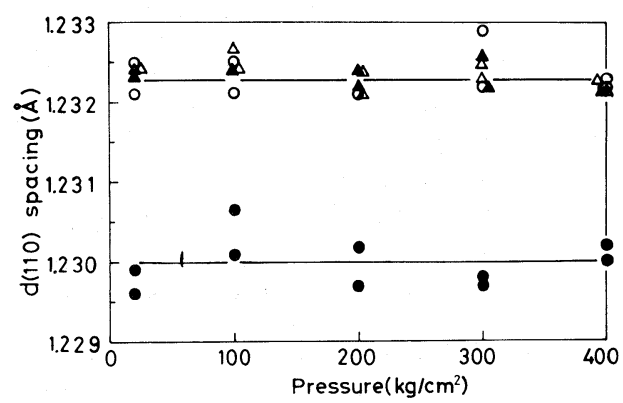

Fig. 9 Changes of $d_{(110)}$ spacing of coke with hot-pressing pressure.

0 : no addition,

$0: 4.8 \mathrm{wt} \%$ boron carbide addition,

$\Delta$ : $9.1 \mathrm{wt} \%$ boron carbide addition, $\triangle: 16.7 \mathrm{wt} \%$ boron carbide addition 
変化の例を Fig. 10 に，また， $L_{c(112)}$ の変化をFig.11 に 示す。炭化ホウ素を添加したコークスの(112)回折線は 圧力の増加とともにその強度は弱く，かつブロードにな り， $L_{c(112)}$ 屯圧力の增加とともに次第に減少している。 このことは炭化ホウ素を添加した焼成体に扔いては，木 ットプレス压力が増加するとコークスの黒鉛構造の規則 性が低下するととを示している。

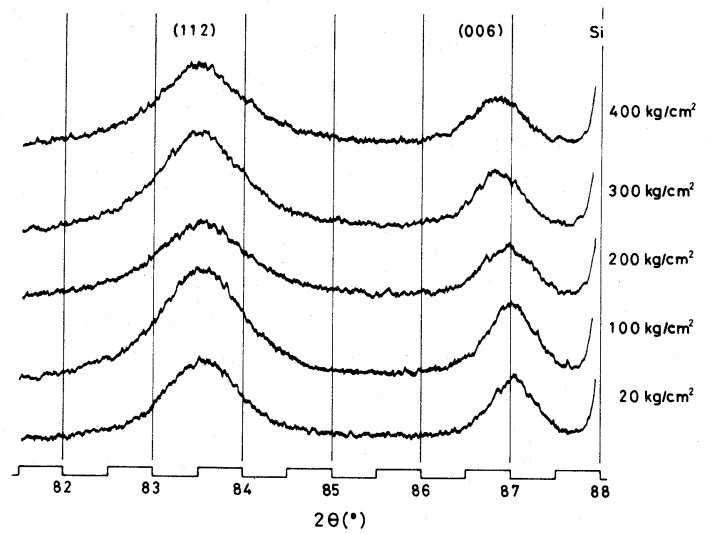

Fig. 10 Changes of (112) diffraction profiles of coke with $9.1 \mathrm{wt} \%$ boron carbide in the original with hot-pressing pressure.

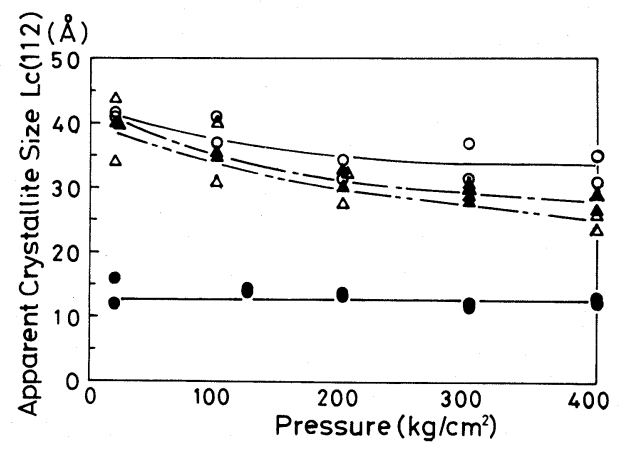

Fig. 11 Changes of apparent crystallite size, $L_{c(112)}$, of coke with hot-pressing pressure.

: no addition,

$0: 4.8 \mathrm{wt} \%$ boron carbide addition,

$\Delta$ : $9.1 \mathrm{wt} \%$ boron carbide addition,

$\triangle: 16.7 \mathrm{wt} \%$ boron carbide addition

\section{5 空気酸化および湿式酸化}

$4.8 \mathrm{wt} \%$ 炭化ホウ素焼成体および市販の黑鉛材の空気 酸化打よび湿式酸化試験結果を Fig. 12 および 13 亿示す。 なお，Fig.13に扔いて，粉末化したあのは除いてある。

空気酸化試験に打いて, 市販品 $\mathrm{A}$ の場合には 0.5 時間 後にすでに酸化により表面に穴が生じ，その穴の数は試 験時間が長くなるにしたがって増加し，3時間後には試
片は原形をとどめないほど小さくなっている。市販品 $\mathrm{B}$ の場合にはAのように穴は生じないが，すでに 0.5 時間 後から表面が粉末状化しはじめ，3時間後には原形をと どめないほど粉末状に変化した。一方, 炭化ホウ素添加 焼成体では，3 時間後であ表面が若干荒れる程度で，充 分に原形をとどめている。との表面の荒れは，加圧力が 大きいほど少なかった。無添加の場合には，ほとんど原 形をとどめないほど酸化により粉末状化した。

湿式酸化試験において, 市販品 $\mathrm{A}$ および $\mathrm{B}$ は, 5 分後 にはすでに膨潤しはじめ, 30 分後には, 試験前の 2 倍 以上の体積に膨れている。一方, 炭化ホウ素添加焼成体 の場合には, $20 \mathrm{~kg} / \mathrm{cm}^{2}$ ののむ除いて, 表面は若干荒 れているあのの， 30 分後においてあいずれも原形を之 どめて戈り，かつ，市販品の様に膨潤等の現象は観察さ れない。また，表面の荒れは，炭化ホウ素の添加量が多 いほど少なかった。

以上の実験結果から，炭化ホウ素をコークス粉末に添 加して $2200^{\circ} \mathrm{C}$ で加圧焼成すると，無添加の場合に比較 してち密化および黒鉛化が進行するが，ホットプレス圧 力を大きくするとそのち密化之焼結を著しく進行させ， 一方では黒鉛化をやや低下させることが判った。すなわ ち，ち密化についてみると，無添加の場合には圧力が $400 \mathrm{~kg} / \mathrm{cm}^{2}$ でも相対密度 $85 \%$ ，曲げ強度が 150 200 $\mathrm{kg} / \mathrm{cm}^{2}$ であるのに対し，炭化ホウ素添加の場合には圧 力の増大ととあにち密化は著しく進行し， $400 \mathrm{~kg} / \mathrm{cm}^{2}$ では相対密度 95〜96\%，曲げ強度 800〜1500 kg/cm²の 焼成体が得られた。しかし，黒鉛化についてみた場合， 無添加にくらべて著しく進行するが, 圧力の増大ととも にd $d_{(002)}$ は $20 \mathrm{~kg} / \mathrm{cm}^{2}$ の $3.358 \AA$ からら $400 \mathrm{~kg} / \mathrm{cm}^{2}$ の 3.362 ̊と次第に増大し，乙れととあにみかけの結晶子の大き さは次第に減少し，(112)回折線はブロード化し, 強度 は弱くなり黒鉛構造の規則性は低下する傾向を示した。

ホウ素原子が黒鉛構造中へ置換固溶することはすでに 知られており, 置換固溶によって黒鉛の $d_{(002)}$ 值は減少 し， $d_{(110)}$ 值は増加し，見掛けの結晶子の大きさは增大 する ${ }^{5,6,7,8)}$ 。さきに筆者らの実験で炭化ホウ素を添加し たコークスの加圧燒成においても同様な現象が認められ， その置換型固溶限界量は $2200^{\circ} \mathrm{C}$ で $2 \mathrm{wt} \%$ 前後之推定し $た^{2,3)}$ 。また，その場合，添加するホウ素量が多くなり， 置換型固溶限界量を充分に越えたホウ素量(約 $4 \mathrm{wt} \%$ 以 上，炭化ホウ素として約 $5 \mathrm{wt} \%$ 以上)が存在すると， $d_{(110)}$ 值は変化しないが, $d_{(002)}$ 值は増大し, 見掛けの 結晶子の大きさは減少した。乙れはMarinkovic ${ }^{8)}$ が報告 したように，置換型に加えて侵入型としてホウ素が固溶 するためであると考えた。

さきに筆者ら ${ }^{4)} は$ 、ホットプレス压力の影響を、三酸 


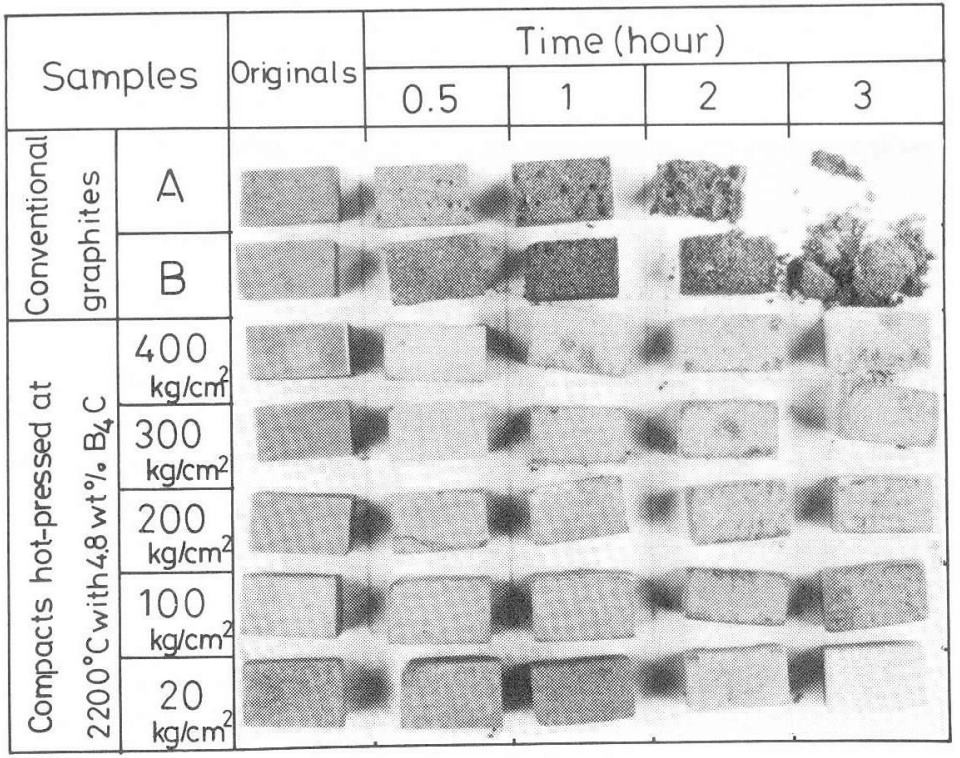

Fig. 12 Photographs of the compacts hot-pressed under different pressure at $2200^{\circ} \mathrm{C}$ with $4.8 \mathrm{wt} \%$ boron carbide addition and the conventional graphites before and after testing for air oxidation resistance at $800^{\circ} \mathrm{C}$.

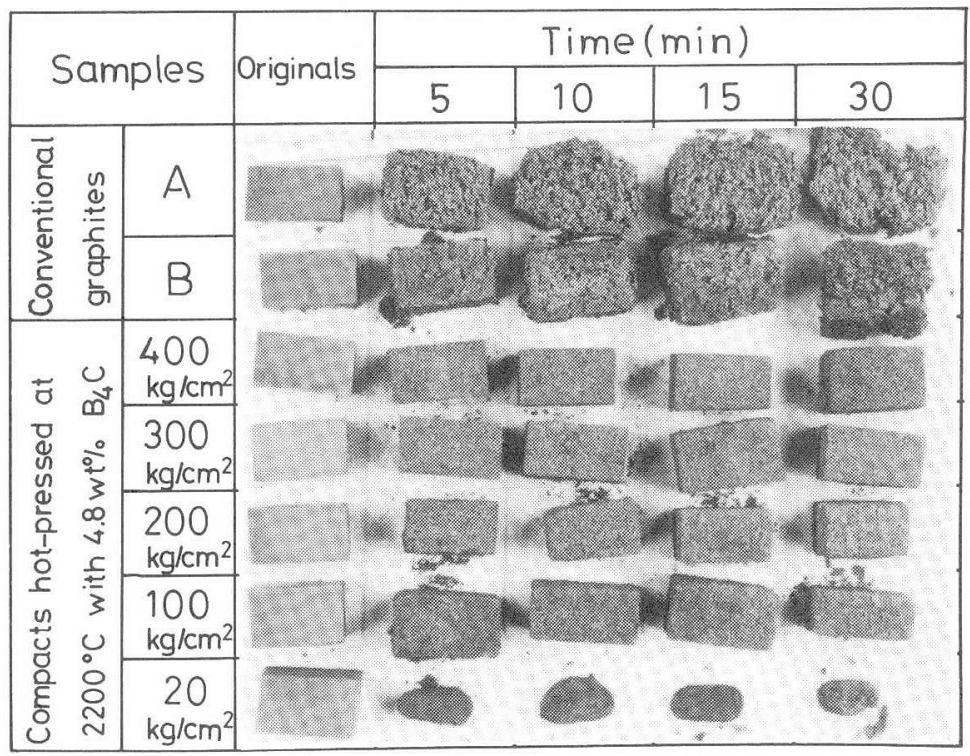

Fig. 13 Photographs of the compacts hot-pressed under different pressure at $2200^{\circ} \mathrm{C}$ with $4.8 \mathrm{wt} \%$ boron carbide addition and the conventional graphites before and after testing for resistance against mixed acid $\left(\mathrm{H}_{2} \mathrm{SO}_{4}: \mathrm{HNO}_{3}=9.1\right)$ at room temperature.
化ホウ素を $10 \mathrm{wt} \%$ (ホウ素量とし て約 $2.8 \mathrm{wt} \%$ ) 添加したコークスに

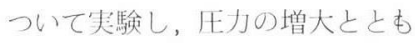
に焼成体の密度书よび强度は著し く增加するが，コークスのX線心 ラメータはほとんど変化しないと いう本实験之異なる結果在得た。 その理由としては次の様に考えた。 前報の実験の場合, 添加した木 ウ素量は約 $2.8 \mathrm{wt} \%$ であり，置換 型固溶のみが起ると考えられる領 域である。その置換型固溶量が400 $\mathrm{kg} / \mathrm{cm}^{2}$ 程度の圧力では影響され ないために，前実験において，压 力を増大させてもコークスのX線 パラメータに変化があらわれなか ったと推定される。

一方, 本実験の場合, 添加した ホウ素量は 3.8〜13.1 wt\%であり, 充分に侵人型固溶屯起ると考えら 机る領域である。また，压力の增 大にとあなって， $d_{(110)}$ 值は変化 しないにあかかわらず, $d_{(002)}$ 值 の增大および $L_{c}$ の減少するとい う現象は，侵入型固溶によるX線 のパラメータの変化の現象に酷似 する。これらのととから，本実験 においては、ホットプレス压力の 增加にとむなって侵入型固溶量が 増加し, 層間距離の增大, 見掛怕 の結晶子の大きさの減少および三 次元思鉛構造の規則性の低下の現 象をあたらしたもの上考えられる。

焼結の効果については，すでに 報告 ${ }^{1,2,3\rangle}$ したと抢り，とくに2000 ${ }^{\circ} \mathrm{C}$ 以上で炭化ホウ素中のホウ素の コークス中への拡散が著しく進行 し，黑鉛化を促進し，同時に焼結 あ進行させるが，本実験において， 圧力の増加とともに焼成体のち密 化之強度が增大したのは, 压力が 高いほどコークス粒と炭化ホウ素 粒あるいはコークス粒同士の粒境 界接触面積か增大し, 気孔量が少 なくなると同時に境界間の原子移 動がより促進されて，粒子間の焼 
結が進行したあのと考えられる。 $400 \mathrm{~kg} / \mathrm{cm}^{2}$ の圧力下 では曲げ強度約 $800 〜 1500 \mathrm{~kg} / \mathrm{cm}^{2}$ の焼成体が得られた が，破断面をみる之粒界破断が大部分であり，焼結をさ らに進行させることにより,さらに材料強度を上げるこ とは可能と推定される。

また，炭化ホウ素を添加して得られた焼成体は，従来 の市販の炭素，黒鉛材と比較して著しく空気酸化抵抗抒 よび湿式酸化抵抗 (耐薬品性)があり，乙の特性は高い圧 力下で得た焼成体ほど良好である。その理由としては， ち密化抢よび黒鉛化が進行したととの他に，コークス中 へのホウ素の固溶㧍よび炭化ホウ素が共存することなど が考えられるが，乙のホウ素の固溶や炭化ホウ素の共存 が, 何故, 耐空気酸化性や耐薬品性にすぐれた特性につ ながるのかは今後の問題である。

\section{4. まとめ}

炭化ホウ素を 4.8～16.7 wt\%の範囲で添加したコーク ス粉末を加圧下で $2200^{\circ} \mathrm{C}$ の熱処理を 60 分間行い，その 加圧力が得られた焼成体の諸物性におよぼす影響を検討 し, 次の結果を得た。

1）無添加の場合には压力が $400 \mathrm{~kg} / \mathrm{cm}^{2}$ でも相対密 度約 $85 \%$ ，曲げ強度 150 200 kg/cm² であるのに対し， 炭化ホウ素添加の場合には圧力の増加とともにち密化は 著しく進行し， $400 \mathrm{~kg} / \mathrm{cm}^{2}$ では相対密度 95 96\%, 曲
げ強度 $800 \sim 1500 \mathrm{~kg} / \mathrm{cm}^{2}$, 電気比抵抗 $0.5 \sim 0.6 \times 10^{-3}$ ohm-cmの燒成体が得られた。

2）炭化ホウ素添加コークスは無添加にくらべて黑鉛化 が著しく進行するが，いずれの添加量の場合にも，压力 の增加とと屯に $d_{(002)}$ 值は $20 \mathrm{~kg} / \mathrm{cm}^{2}$ の $3.358 \AA$ 加ら 400 $\mathrm{kg} / \mathrm{cm}^{2}$ の $3.362 \AA$ ¿次第に增加し，乙れとと屯に見掛け の結晶子の大きさは隇少し，三次元黒鉛構造の規則性は 低下する傾向を示した。

3）炭化ホウ素添加焼成体は，市販の黑鉛材にくらべ て著しく空気酸化抵抗および湿式酸化抵抗(耐薬品性)が あり，乙の特性は高い圧力下で得た焼成体ほよ゙，また， 炭化ホウ素の添加量が多い焼成体ほど良好であった。

\section{文献}

1) 宮崎，小林，本田，炭素，1977〔No.91〕121

2）宮崎，萩尾，小林，窯協，86，618(1978)

3) K. Miyazaki, T. Hagio and K. Kobayashi, $J$. Mater. Sci. 16, 752 (1981)

4) 萩尾, 宮崎, 小林, 炭素, 1978[No.94] 100

5) F. Tombrel, Rev. Hautes Tempér et Réfract, t3, 79 (1966)

6) W. V. Kotlensky, Carbon 5, 409 (1967)

7) C. E. Lowell, J. Am. Ceram. Soc. 50, 142 (1967)

8) S. Marinkovic, C. Suznjevic and I. Dezarov, Carbon 7, 185 (1969) 